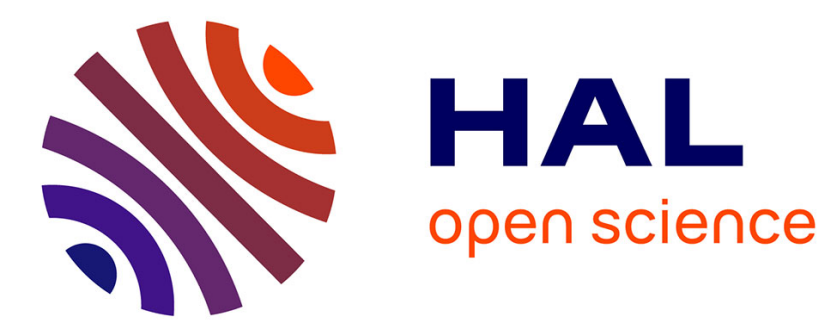

\title{
Whatever Happened to Social Dialogue? From Partnership to Managerialism in the EU Employment Agenda
}

\author{
Michael Gold, Peter Cressey, Evelyne Léonard
}

\section{To cite this version:}

Michael Gold, Peter Cressey, Evelyne Léonard. Whatever Happened to Social Dialogue? From Partnership to Managerialism in the EU Employment Agenda. European Journal of Industrial Relations, 2007, 13 (1), pp.7-25. 10.1177/0959680107073963 . hal-00570956

\section{HAL Id: hal-00570956 https://hal.science/hal-00570956}

Submitted on 1 Mar 2011

HAL is a multi-disciplinary open access archive for the deposit and dissemination of scientific research documents, whether they are published or not. The documents may come from teaching and research institutions in France or abroad, or from public or private research centers.
L'archive ouverte pluridisciplinaire HAL, est destinée au dépôt et à la diffusion de documents scientifiques de niveau recherche, publiés ou non, émanant des établissements d'enseignement et de recherche français ou étrangers, des laboratoires publics ou privés. 


\title{
Michael Gold, Peter Cressey and Evelyne Léonard
}

Royal Holloway University of London, UK, University of Bath, UK and

Université catholique de Louvain, BELGIUM

\section{Whatever Happened to Social Dialogue? From Partnership to Managerialism in the EU Employment Agenda}

\begin{abstract}
There has been a major bifurcation in the level and form of social dialogue between employers and unions within the EU. The intersectoral and sectoral social dialogue launched by the Val Duchesse process in 1985 now runs in parallel with domestic forms that are merely reacting to agendas established by the Commission and the Council. This article, based on interviews with employer, union and government representatives across six EU member states, argues that the European Employment Strategy is converting social dialogue into a managerialist process by decentralizing it to national level and co-opting the social partners into taking responsibility for meeting employment targets over which they have had no influence.

KEYWORDS: European employment strategy - managerialism - open method of coordination - social dialogue - social partners
\end{abstract}

\section{Introduction}

One central element of the 'European social model' has been the inclusion of the social partners in the development of policies and initiatives at EU level. Under this model, trade unions, employers and public sector organizations have engaged in a range of participatory processes, including in recent years the formulation of directives across a variety of social and employment areas. Some commentators (Lecher et al., 2002) have claimed that this is a new form of policymaking that contributes to a unique European path that can simultaneously combine economic progress with social involvement. Since the Maastricht Treaty and, more recently, the Essen and Lisbon Councils, social dialogue has been consolidated in all social policy formation and implementation.

Social dialogue according to the Commission (EC, 2002b: 4) is the driving force behind successful economic and social reforms' and must be embedded at different levels of EU activity. In particular, social partner 
involvement is described as central to the emerging 'open method of coordination' (OMC), defined by the Lisbon Council as: the use of common EU-wide guidelines, timetables and goals; the use of indicators and benchmarks; the translation of EU guidelines into national and regional policies, taking differences between the member states into account; and monitoring, evaluation and peer review (Council, 2000: para. 1.18.37).

The European Employment Strategy (EES) is the first European process where all four of these elements are applied and roles are assigned to the social partners, especially in relation to monitoring, evaluation and peer review (De la Porte and Pochet, 2003). In the EES, the participation of social partners at European and national levels is considered an important feature of the 'governance' of the process. This has been stated from the outset, and was reasserted in the presentation of the Employment Guidelines for the period 2005-08: 'Member States should ensure good governance of employment policies. They should establish a broad partnership for change by involving parliamentary bodies and stakeholders ... European and national social partners should play a central role' (Council, 2005a: 23).

This article traces the evolution of social dialogue at EU level and examines the extent to which it has fulfilled the claims made for it (EIRO, 2005; Kok, 2003; Zeitlin et al., 2005). It argues that social dialogue at EU level reached its greatest influence with the introduction of the 'negotiation track' in the Maastricht social chapter, which allows the Commission to create directives (binding legislation) out of agreements concluded by the European social partners. However, the EES places emphasis on national levels of social partner involvement, which can be considered 'decentralized' from a European point of view, but which correspond to a broadly corporatist type of national cross-industry and tripartite dialogue. Involvement in the EES is therefore dependent on national institutions and practices, whereas beforehand the social dialogue relied on the willingness of social partners at EU level to create their own 'space'. The Stockholm summit in March insisted that 'success ... requires commitment from employers and workers at the grass roots' (Council, 2001c: para. 1.18.30, emphasis added).

An evaluation of the role of social dialogue in the OMC therefore requires analysis of its impact both at EU level and within each member state, where responsibility lies for the delivery of the EES.

\section{Emergence of Social Dialogue at EU Level}

There are many accounts of the evolution and significance of EU social dialogue (De Boer et al., 2005; Keller and Platzer, 2003; Keller and Sörries, 1999; Teague, 1999). From the 1980s onwards, the Commission recognized that the development of a European industrial relations area 
required, first that there should be 'strong and capable social partners' who are European in their conception and administration of policy; and second, that the social dialogue should be deepened and extended to act as a regulatory instrument enabling the 'harmonization of employment and working conditions' (EC, 1988: 88-9) alongside other regulations and directives. The discussions which took place before the 1989 Social Charter and the 1991 Maastricht Treaty acknowledged the obstacles to harmonizing conditions across the heterogeneous systems of industrial relations in the member states. Nor was there any conception of how social partner regulation could bear upon existing national levels of collective agreement. However, social dialogue was considered important, first as an institution-building process necessary as a precursor to any European industrial relations system, and second as a potential joint regulatory procedure alongside other more centralized and legalistic forms.

These functions of social dialogue were reinforced by the social protocol of the Maastricht Treaty, consolidated as the social chapter of the Amsterdam Treaty in 1997. The social partners were then drawn into two related variants of social dialogue, one involving what was termed the 'negotiation track' and the other 'autonomous' or 'voluntary agreements'. Both are based on Article 139 of the Treaty; ${ }^{1}$ according to the Commission, 'the social partners' right to be consulted on proposals in the social field and their option to request that matters be dealt with by agreement rather than legislation brought them to the centre of the European social stage' (EC, 2002a: 17).

Under the first track, the Commission consults the social partners over the topics for negotiation, and Community institutions subsequently intervene, at the Commission's initiative, only if there is failure to agree. Since 1993 the social partners have been directly consulted 12 times in this way (EC, 2004). The outcome may be independent social dialogue, at intersectoral or sectoral levels, and ultimately agreements which may establish minimum standards to be incorporated into Community law. Intersectoral framework agreements implemented by means of directives have covered parental leave (1995); part-time work (1997); working time in sea transport (1998); fixed-term contracts (1999); mobile workers in civil aviation (2000); and working conditions of mobile workers in cross-border services (2004).

Furthermore, since the Laeken Declaration (2001) the social partners have placed greater emphasis on bipartite 'autonomous agreements'. These are negotiated without any intervention from the Commission, and implemented either by collective agreement in the member states or by Council Decision on request from the social partners (EC, 2003). Two such agreements have been concluded, the first in 2002 on telework and the second in 2004 on work-related stress.

The Commission has thus been cementing its aim of creating 'strong and capable social partners' within new regulatory instruments. The main 
thrust has been an attempt to strengthen workers' rights, linking back to the Commission's traditional approach to social and employment policy in the 1970s of building strong industrial relations institutions and representative bodies within a developing European area of employment relations. However, the results have sometimes been contested (De Boer et al., 2005), and the processes remain partly dependent on the Commission. In recent years, the flow of its proposals has also declined as the 'shadow of the law' has faded (Falkner, 2003).

\section{The Open Method of Coordination: A New Form of Managerialism?}

Priorities soon changed from greater employee rights to employment creation (Gold et al., 2000). The 1993 White Paper Growth, Competitiveness and Employment (EC, 1993) stressed the role of training, flexibility and work re-organization in reducing the level of unemployment; while the December 1994 Essen Council recommended, amongst other measures, that member states should give greater weight to active labour market policies and target groups particularly at risk of unemployment (Council, 1994: para. 1.3).

The Luxembourg summit in November 1997 inaugurated a new form of policymaking by introducing the EES (Goetschy, 1999). Under the terms of the 'Luxembourg process', each member state was required to draw up an annual National Action Plan (NAP) for employment. Over the first five cycles of the EES, from 1998/9 to 2002/3, each NAP had a standardized format, with four 'pillars' (employability, entrepreneurialism, adaptability and equal opportunities) each subdivided into some 20 more detailed guidelines. In 2001 they were supplemented by six 'horizontal objectives' which incorporated the Lisbon targets noted below. The EES has since undergone successive reforms, notably in 2003 when the number of guidelines was reduced and the link with the Lisbon objectives reinforced, along with the introduction of detailed quantitative targets and benchmarks. The system was simplified, and the pillars and guidelines were streamlined into the so-called 'ten commandments' (Watt, 2004). In 2005, the strategy was again revisited by the Commission and Council. There are now only eight guidelines, defined for the period 2005-08. According to institutional texts (Council, 2005a), employment policies are more integrated with macroeconomic and microeconomic policies. Nevertheless, the philosophy that underpins the Luxembourg process remains intact, with its reliance on common guidelines, indicators, decentralization and evaluation.

This system depends for its implementation on a process that was laterat Lisbon, in 2000 - to become known as the OMC. This consisted of a decentralized but coordinated process, which had grown out of the broad 
economic policy guidelines that governed the introduction of Economic and Monetary Union (Hodson and Maher, 2001). Its application to employment policy can be traced to the 1994 Essen Council, which called on member states to transpose its conclusions into policy through 'multiannual programmes' (Council, 1994: para. 1.3). A variety of policy areas were soon integrated through the use of OMC, including employment, creation of the information society, research policy, social inclusion and pensions, with each accompanied by appropriate benchmarks. The OMC has been increasingly used to coordinate policy areas that are regarded as particularly complex, delicate and institutionally embedded at national level (Borrás and Jacobsson, 2004; De la Porte and Pochet, 2003; Goetschy, 2005; Scott and Trubek, 2002; Zeitlin et al., 2005.)

Since the inauguration of the Luxembourg process, EU social policy has targeted 'the promotion of employment' (Article 136), with goals and benchmarks set by the Commission and Council (the social partners have not been involved in target-setting). The Lisbon Council of March 2000 set a 10 -year strategy for 'boosting employment, economic reform and social cohesion within the framework of a knowledge-based economy' (Council, 2000: para. 1.1), specifying a target 70 percent employment rate across the EU by 2010.

The OMC, then, entails target-setting, and its implementation redirects social dialogue away from means - the establishment of procedures and processes - and towards goals involving targets across a range of indicators. In this sense, the redirection moves away from the principle of autonomy of bargaining and towards a form of managerialism that has been prevalent in the UK, especially in relation to new forms of public sector management. There, improvements in efficiency and quality were to be procured by close scrutiny of performance and enhanced monitoring of newly created benchmarks (Cutler and Waine, 2000). The parallel in European terms is the integration of multiple policies into the OMC, with multiple benchmarks. It applies, as noted above, to many fields of interest to the social partners, including employment, social inclusion and pensions. Officially the social partners make a dual contribution to this process: 'on the guidelines and the process itself, the social partners are regularly consulted ... on the content, the social partners are sometimes in a position to provide responses to guidelines determined in the context of the open coordination method. This is particularly relevant as regards employment ...' (EC, 2002a: 14-5).

The annual Tripartite Summit for Growth and Employment, held for the first time in 2003, reflects the same principle of consultation with social partners at European level: it aims at 'exchanging views' and examining social partners' contribution to achieving the Lisbon objectives, but it does not set its own agenda or engage in establishing the objectives themselves. 
To what extent have these changes strengthened or weakened the social dialogue? Developments so far show that in the OMC the domestic intersectoral level has been privileged and that, whilst there are claims for 'a central role' (Council, 2005a: 23) for social partners, these remain at the periphery of the process. The new phase signals a change in both the level and the form of social dialogue, shifting to a national arena supported by a managerialist agenda. The first five-year period of the Luxembourg process provides a convenient and self-contained timeframe for analysing this and the extent of those changes in the different national settings.

\section{The Luxembourg Process: A New Variant of Social Dialogue}

The OMC has, then, brought about a new phase in the social dialogue. The negotiation track and the option for 'autonomous agreements' run alongside, it is true, and remain influenced by a Commission-led agenda. Nevertheless, the OMC variant of social dialogue involves a change in level, in that the social partners in each member state are requested to advise, consult and possibly negotiate on the ways to achieve labour market targets agreed by the Council, which unambiguously sets the agenda. From an existing 'option to request that matters be dealt with by agreement rather than legislation' (EC, 2002a: 17), and therefore the chance of a vital role in the governance of the EU through early involvement in key European issues, the role of the social partners in the EES has been greatly downgraded. They have no part whatever to play in the setting of the various guidelines, pillars and targets in the EES, and their participation has been moved 'downstream' to national level, where they are merely expected to implement the policy that has been established well 'upstream'.

Yet the Luxembourg summit had underlined the role of the social dialogue in the NAP process: 'the social partners at all levels will be involved in all stages of this approach [the drawing up of the NAPs] and will have their contribution to make to the implementation of the guidelines. That contribution will be regularly assessed' (Council, 1997: para. 1.4.18). The clear implications here are that the social partners would be involved at both EU and national levels in a forward-looking strategy on employment, with regular evaluation of their input.

The evaluation of social partner involvement has been critical. The Commission, for example, observed that the 'social partners' commitment to the NAPs process varies from one member state to another'. In relation to modernizing work organization, it noted that 'their relative absence ... in the EES process has clearly to be seen as one of the weak features of the strategy'. Overall, it concludes that lack of social partner involvement has been a 'weak spot' of the EES (EC, 2002b: 14, 27, 40). 
Furthermore, in the Joint Employment Report 2004/05, the Council implicitly recognizes that consultation, rather that real participation, is the rule. 'The European Council called on Member States to establish partnerships for reforms. While partnership approaches exist in many Member States, Ireland was the only one to cite the establishment of reform partnerships in its NAP' (Council, 2005b: 19).

The European Trade Union Confederation (ETUC) has been similarly concerned. In a questionnaire circulated to its members in 2002 it asked: 'have your public authorities developed a comprehensive partnership for implementing and monitoring the EES?' (ETUC, 2002). The variation in response was striking. The Belgian FGTB-ABVV, for example, replied that work on the EES was carried out in the bipartite National Labour Council, whilst the Danish FTF stated that there had been ongoing consultation over the incorporation of social partner contributions to the NAP in 2002, and some had been accepted. In Germany, the ministries responsible have involved the DGB by sending it provisional draft texts of the NAP in good time and allowing it the chance to propose additions and amendments. The French CFDT and the Spanish CC.OO., by contrast, replied that there was no such partnership, and the British TUC commented that involvement was ad hoc as there were no institutional arrangements designed to bring the government and social partners together. Partly as a result of these concerns, a conference on the theme Contribution des partenaires sociaux was convened in February 2002 for social partners from 12 member states to discuss employment-friendly practices. It subsequently led to an EU-wide network of national social partners involved in their countries' NAPs, but an assessment of its activities is not available (EIRO, 2002).

More recently, the ETUC published a report on trade union evaluation of the EES (Homs et al., 2005). The unions concluded that the EES had usefully given increased political visibility to employment issues and had defined objectives, allowing an assessment of the progress made. However, in their critique, they underlined the prevalence of institutional relationships between the national governments and the Commission with little space for 'co-responsibility' with social partners.

European unions and employers have also joined forces to produce a common evaluation. In 2004, ETUC, UNICE/UEAPME and CEEP issued a 'Report on Social Partners' Actions in Member States to Implement Employment Guidelines' (ETUC et al., 2004). Their observations covered 14 of the EU-15 countries. In only four has there been participation, while in the 10 others consultation has taken place but with little impact. The way in which the question was formulated, focusing on the role of the social partners in the 'implementation' of the guidelines is, as such, indicative of the mainly reactive role that national unions and employer organizations play in the EES. 


\section{Social Partner Involvement: Dynamics at Play}

In an attempt to analyse in greater detail the involvement of the social partners in these processes, this article presents the findings of a project carried out in 2002-3 and funded by the UK Economic and Social Research Council (see the Acknowledgements and also Casey, 2005). It focused on six member states, selected according to their contrasting levels of labour market participation. Greece, Spain and Belgium (55.5, 57.7 and 59.9 percent respectively) can be regarded as 'poor' performers; Ireland, the UK and Denmark (65.8, 71.7 and 76.2 percent) as 'moderate' or 'high' performers (Eurostat). They also have contrasting industrial relations systems, ranging between highly institutionalized traditions of bipartite bargaining and tripartite concertation (Belgium, Denmark) to the opposite (Greece, UK). Semi-structured interviews were carried out in spring 2003, at the end of the first five-year EES evaluation period, with representatives of the principal social partners and government officials from the ministries of labour and social affairs, or their equivalents. An attempt was made to explore perceived involvement in the annual NAP cycles and its relationship with outcomes - that is, the extent to which the level of social partner involvement could be associated with favourable labour market results.

The social partners in this context are those organizations representing employers and workers at national level in each member state. It is important to keep distinct the process of social dialogue at EU level - a creation of the EU itself, and a genuinely pan-EU method of regulation - and the multiple processes of negotiation, consultation and information that take place within the strictly national confines of each member state. The industrial relations frameworks that structure such national systems of 'social dialogue' are immensely complex, with wide variations in scope, level and regulatory basis, depending on history and tradition (Ferner and Hyman, 1998; Van Ruysseveldt and Visser, 1996). Nevertheless, the success of the EES largely rests on the performance of these national systems (EIRO, 2005). The efficient insertion of young people into the labour market, the promotion of female employment and the retention of older workers in paid work, for example, depend at least partly on the cooperation of the social partners in ensuring the smooth operation of the systems designed to achieve these objectives. Moreover, in many countries issues such as flexibility, working time, and training and development are regulated mostly by employers and unions at various levels of the industrial relations system.

Yet the social partners did not participate in any way in setting the targets adopted at the Lisbon and Stockholm summits. They were adopted unilaterally by the Commission and subsequently by the Council without reference to how practical or realistic they were in the eyes of EU-level employers' organizations or unions, the very parties 
subsequently responsible for implementing and monitoring them. In this way, they were placed in a position of responsibility without power or influence, and required to support the achievement of objectives over which they had had no control. This point is significant as it reflects the managerialist orientation of the EES. In the course of joint negotiations, employers and unions are generally free to establish their own agendas, timetables and work methods. However, the Luxembourg process has removed this area of autonomy from the competence of the social partners at national level, assuming that they will be prepared to participate in a process over whose objectives they have had no say.

With these provisos, involvement can be examined in a variety of different ways: for example, the stage at which the social partners are involved in drawing up the NAP; the degree to which they are integrated into the peer review processes; and the control that the government exerts over methods of involvement. The following sections analyse these various elements, but also examine the ways in which the social partners are occasionally able to use the NAP process to their own advantage, by focusing on those issues that most meet their current interests. Implementation, monitoring and evaluation of the NAPs remain patchy, and reflect variations in the capacity of diverse national systems of industrial relations, but one of the principal problems with social partner involvement is that the NAPs are still designed as compilations of existing policies rather than as forward-looking strategic plans.

\section{Stages of Involvement}

The stages at which the social partners become involved in the NAP process vary widely. In Spain, the employers' confederation CEOE submitted written comments to the Ministry of Labour on the draft NAP, and met officials, but described the procedures as 'routine'. The Workers' Commissions (CC.OO.) had not recorded any change over the five years under review: union officers were sent the draft NAP for comment but never met the Ministry of Labour for discussions, or the employers. The government had amended the NAP in the light of comments, and a late version was discussed, according to the Ministry of Labour, by the Economic and Social Council (CES), but CC.OO. called for the opportunity to make comments before the first draft was written.

Similarly in Greece, the government used to send the social partners the final draft of the NAP for their opinion, though changes were introduced in 2002: the social partners were involved earlier and there were three drafts before the final version. The government had created four working groups on the NAP, one for each pillar, and the Federation of Greek Industries (SEB) made submissions to each. In the UK, the Department 
for Work and Pensions (DWP) drafts the first version of the NAP, and its status does not allow serious amendment. The Confederation of British Industry (CBI) and the TUC are more involved towards the end, but the TUC described the process as 'a bit of a ritual'.

By contrast, the social partners are involved more coherently, and at earlier stages, in Belgium, Ireland and Denmark. The first draft of the Belgian NAP contains contributions from the regional governments and social partners, as fed through the country's bipartite National Labour Council. However, the joint statement it issued in September 2003 evaluating the two-yearly intersectoral agreement stated that the then current process was 'opaque' and that the social partners wanted greater involvement in drawing up and monitoring the employment guidelines. In Ireland the Department of Enterprise, Trade and Employment (DETE) requests information from the social partners under certain headings before it begins to draft the NAP. It then produces a preliminary version, which is refined as the social partners make further comments. Though they do not sign, the social partners may append their own views. Similarly, the social partners in Denmark make their own contributions to the NAP, which they submit to the Ministry of Labour, which in turn drafts the NAP taking their views into account. The government composes the final version, though the NAP contains appendices with social partner contributions. The social partners themselves stressed that there was a high degree of consensus in Denmark on active labour market policy, which was discussed regularly on the then national-level Labour Market Board.

Though social partners in all the countries covered criticized the lack of time available to put the NAP together - a criticism that has been taken into account in the revised versions of the EES introduced since 2003 - it is remarkable how diverse national procedures have proved in involving them earlier or later. In some, and particularly in countries where a tradition of tripartite consultation existed already before the Luxembourg process, they participate at the earliest stages of drafting, whilst in others they are merely shown the final draft for late comment.

\section{Peer Review}

Participation at the round of peer review meetings convened by the Commission varies too. In the UK, the process is stage-managed, with a pre-meeting between the government, CBI and TUC to decide who will answer which points. The Greek government had asked the General Confederation of Greek Workers (GSEE) to attend, along with three employers' organizations. SEB had attended only in 2002, and a special advisor to the government described the questions raised at the meetings as 'fixed' in line with the Commission's current agenda. The Danish 
Federation of Trade Unions (LO) saw little value in the follow-up bilateral meetings with the Commission, and attended only for public relations purposes with its members. The Irish Congress of Trade Unions (ICTU) refused to attend altogether - unlike the Irish Business and Employers' Confederation (IBEC) - because neither the government nor the Commission would pay their expenses. Attendance by the Spanish social partners was also erratic: CEOE had gone in 2002 only to explain to the Commission the role of temporary contracts in Spain. By contrast, Belgium sent a large delegation to bilaterals: up to 30 people, representing federal and regional government, political advisors to the Ministry of Labour, along with the social partners themselves.

Overall, patterns of attendance vary, which may seem surprising given the significance of the process for peer review. Attendance may be seen as a ritual, or undertaken for public relations purposes. Not all social partners go along every year, and some plan their contributions at premeetings, whilst others do not. Some delegations are focused, whilst others are inclusive.

\section{Role of Government}

Responsibility for the NAPs lies with the member states. In the UK, for example, the DWP initiates the drafting process, and the Treasury, the Department of Trade and Industry and the CBI and TUC are regarded as 'strategic partners'. However, as one official stressed, 'it's our Secretary of State who signs it off'. Partly as a consequence, two contentious points in the UK NAP had never been resolved. Guideline One in 2001 had required the offer of a job 'before' reaching six months of unemployment for young unemployed and 12 months for adults (Council, 2001a: 21). This point was stressed in the Council's recommendations to the UK (Council, 2001b: 37), though the DWP insisted it had no intention of altering its current policy, the offer of a job 'at' six months. A year later, the Council recommended that the UK should 'further foster social partnership at the national level, in particular to improve productivity and skills, and the modernization of working life' (Council, 2002: 80). The TUC supported the Commission on both issues, but the DWP held its ground. Furthermore, the DWP itself noted that its model for active labour market policy is drawn more from the USA than from Europe, so attempts by the TUC to use 'best practice' from France and Germany tended to elicit the response: 'but just look at their unemployment'.

Indeed, other countries too have proved resistant to EU pressure when key interests were at stake. The Council in its recommendations has criticized both Belgium and Denmark on account of their failures to prevent the early withdrawal of workers from work (Belgium: Council, 2001b: 29 
and 2002: 72; Denmark: Council, 2001b: 30). Nevertheless, the Belgian intersectoral agreement for 2003-4 merely extended the existing rules on early retirement for a further two years, and did not mention the age at which workers became eligible for it (EIRR, 2003). Tensions during autumn 2005 on the Belgian government's 'pact for solidarity between generations', which aimed to restrict opportunities for early retirement, reveal that there is clearly still no consensus on certain policy orientations defined by the EES. Similarly in Denmark, the government led by the Social Democrats lost the general election in November 2001 to a coalition led by the Liberal Party, at least partly because of its attempts to reform early retirement. The incoming government accordingly left the issue well alone.

\section{Existing Policies}

A further reason for lack of social partner influence over the NAP process is that many of the policies incorporated into the NAP were already scheduled for introduction. CEOE argued that the Spanish NAPs did not affect domestic industrial relations agendas, but rather that the domestic agendas get incorporated into the annual NAP cycle. The Danish social partners maintained that they produced the NAP every year only because the Commission demanded it. They regarded it as a showcase for Danish active labour market policies, as it told a 'good story'. The NAPs may have helped to stimulate policy, for example in the field of gender mainstreaming, but they had not 'caused' it. The CBI and TUC expressed similar points. The TUC maintained that key policies like the New Deal, lifelong learning, Job Centres Plus and the promotion of Learning and Skills Councils through the Regional Development Agencies would all have taken place without the NAPs, whilst the CBI claimed that the UK government was doing ' 95 percent of the NAP anyhow'.

The ICTU summarized by stating that the Irish NAPs were not 'where the action is'; they were a compilation of policies under way elsewhere, and acted merely as a 'sweeper' for issues that might otherwise have been overlooked (a point explored below). National priorities were covered in the three-year intersectoral agreements, at the time entitled 'Sustaining Progress' (2003-5). This included issues like lifelong learning, university fees and learning leave, which were then integrated into the NAP, which simply provided an opportunity for reflection. Activity also centres on the National Development Plan and the monitoring committees of various operational programmes, such as training. These activities feed through into the NAPs, which are themselves, however, regarded as 'second-line mechanisms'.

Overall, the NAPs were regarded as backward-looking compilations of policy, and not forward-looking strategic plans. They reflected the existing 
concerns of the social partners, whose strategic objectives were actually focused elsewhere, notably on intersectoral bargaining in countries like Belgium, Denmark and Ireland. This partly explains why social partners see the process as somewhat ritualistic: it remains out of the scope of collective bargaining and 'real' partnership, and governments are seen as more anxious to receive a good report from the Commission than to engage in the codetermination of labour market policies.

\section{Pragmatism}

Nevertheless, both governments and social partners do, on occasion, exploit the opportunities presented by the NAP process when it suits their purposes. The DETE in Ireland and the Ministry of Labour in Belgium had used the NAP process to justify labour market activation measures, and they also both stressed that it had helped them to introduce an evaluation culture that made their officials more results-oriented.

The social partners too have often successfully picked up similar opportunities, though these tended to cluster round 'employability' and 'equal opportunities'. For example, the Greek social partners, who finance the country's public employment service, have lobbied for the reform of the service - reform had long been one of their grievances - in line with the Council's recommendations. The Danish LO successfully secured an agreement on the integration of ethnic minorities into the labour market. In Ireland, the ICTU had raised the issue of lifelong learning, particularly workplace learning for people lacking secondary education, while both IBEC and ICTU had campaigned against the lack of childcare facilities, in line with Council recommendations. Similarly, CC.OO. in Spain gave directions to its affiliate unions to include gender issues in their bargaining agendas. In these ways, NAPs have been used as a resource by the social partners to underpin their own policies and campaigns, though issues involving 'entrepreneurship' and 'adaptability' did not feature as prominently.

The impact of NAPs on domestic bargaining varies too. The TUC claimed that in the UK it was 'nil' because bargaining is so decentralized. In Greece, too, GSEE has wanted to place items raised by the NAPs notably labour flexibility, by which it means the reduction in the working week - on bargaining agendas but 'nothing has happened'. By contrast, though it managed to raise gender mainstreaming at intersectoral level, the issue had not yet percolated through to company-level agreements. Spain, too, has had a series of intersectoral agreements covering items like atypical work and dismissals, which have been reflected in the NAPs, but there is no constructive dialogue within the NAP process itself. Belgium has also addressed certain issues raised by the Commission in its cycle of two-year 
intersectoral bargaining, and intervening sectoral bargaining, though contentious issues - such as early retirement - may be fudged. In Denmark, the unions have the strength to ensure compliance with agreements at all levels, and the social partners there pointed out that the implementation of the EES assumed the existence of structures that allowed or promoted the systematic cascade of appropriate policies to achieve the required targets. For example, joint DA/LO statements on the quality or work had been followed up promptly at plant level, in a way that could not be guaranteed in more decentralized systems.

\section{Conclusions}

The position of social dialogue in Europe remains one of contrasts: the older variants established by the Val Duchesse process persist and develop, with policy initiatives and activity evolving at intersectoral and sectoral levels. At EU sector level, for instance, there are now more than 30 social dialogue committees where discussions and negotiations take place. ${ }^{2}$ Running parallel, and with little impact on these processes, is the social dialogue analysed in the latter sections of this article. Reliance on decentralized, national procedures has resulted from the shift towards the employment agenda heralded especially by the Luxembourg and Lisbon processes. The predominance of employment creation, the search for global competitiveness and the holy grail of labour flexibility are all encountered in the new policy agenda set by the EES. With it has come a new approach to social dialogue, a variant that differs from the style of social dialogue encountered previously.

This article has argued that there has been a decisive shift in the level and form of social dialogue since the Essen Council and the subsequent introduction of the OMC. In the EES, the location of social dialogue has been redirected away from the EU intersectoral and sectoral levels towards 'decentralization' at the national level. This means that the domestic form of social dialogue implied by the EES is increasingly distinct from the intersectoral and sectoral kind at EU level, and has become entirely reactive to an agenda set elsewhere. Whereas the social dialogue at EU level allows the social partners to focus on the issues important to them, at national level they merely share responsibility for the implementation of a whole series of targets set elsewhere within the EES. This is a much reduced form of collaboration, where social partners appear to be co-opted into a process beyond their influence. They do not participate in the determination of the objective, as 'partnership' has been reduced largely to a managerialist façade.

Whilst the 'social dialogue' remains the same in name and on the surface, its content and politics are now very different. The rhetoric of social 
dialogue within the EES is not matched by the reality. Despite the efforts of the Commission and the Council to place the social dialogue at centre stage of the Luxembourg process, the social partners are not systematically involved in all stages of the NAP process, or even in the peer review.

What is left to the social partners in the EES is an involvement that depends on pragmatism, that is, participation in the NAP process insofar it fits in with existing domestic agendas even though it barely affects these agendas. Furthermore, the process does not challenge existing national structures and traditions of participation in the member states. For instance, the UK ignored the Council recommendation issued in 2002 to introduce systems of social dialogue, and relies instead on institutional practices that remain suspiciously traditional. The evidence reveals that social partners in all countries are prepared to comply with targets and recommendations as long as they do not challenge existing practices and traditions. Where the chance existed that such targets and recommendations could make a difference, for example, in the case of the treatment of older workers, then the social partners either ignored them or at best creatively complied with the terms laid down. Much of this pragmatism stemmed from the fact that the partners were not involved strategically in the setting of targets and in deciding the processes to monitor them. The NAP process instead revolved round the compilation of active labour market polices that were generally already in existence. Despite the possibility of peer pressure, governments are able to resist the Council recommendations that do not meet their own priorities, which demonstrates the clear limits to peer pressure. Our article has also revealed the mismatch between the levels of target-setting and achievement of the 'central role' that the Council has claimed for the social partners. Because of widely varying institutional and legal structures across the member states, their capacity to meet the targets varies enormously. Indeed, at national level, there is a great degree of variety in terms of involvement, vitality and inclusiveness.

Such variety calls into question not only the capacity of the member states to transform European objectives into domestic practices, but also, in the long term, the legitimacy of the process itself. Weak social partner participation may result in increasing resistance to the process, especially if EU recommendations to national governments on issues such as flexibility, active ageing and employability become more and more urgent for governments, while the social partners - or some of them - remain reluctant to modify existing compromises and arrangements governing these areas.

How, then, might the social partners' involvement in the NAP process become strategic? The success of the EES and meeting the Lisbon targets depends on the capacity of the social partners to mobilize in their support. However, very few of the social partners interviewed indicated any grassroots support for the process, its aims or its outcomes. Whilst the targets remain set at EU level by the Commission and Council, such a top-down 
approach is unlikely to enthuse the grass roots. At the very least, social partners should be involved in setting the targets in the achievement of which they are so heavily implicated.

Finally, without some transparent mechanism for the involvement of democratic institutions, this form of managerialism will prevail: one that empties social dialogue of its social mission, renders it apolitical and reduces it to nothing more than a technical procedure. The OMC recently entered a period of re-evaluation, the outcome of which was a reduction in the number of horizontal and vertical indicators from around 20 to eight. However useful such a simplification might be, the question remains: is it addressing the fundamental flaws underlying this weak form of social dialogue?

\section{ACKNOWLEDGEMENTS}

The interviews on which this article is based were carried out in 2002-3 by Bernard Casey and Michael Gold with a grant (L216 252008 - National Action Plans: policy transfer and social learning in the EU) from the UK Economic and Social Research Council as part of its 'Future of Governance' programme. The authors thank Bernard Casey, the project coordinator, for his permission to use the data. They also thank the editor and two anonymous referees for their comments on an earlier version of this article. The views expressed are their own.

\section{NOTES}

1 Article numbers throughout this analysis refer to The Rome, Maastricht and Amsterdam Treaties. Comparative Texts (1999), published by Euroconfidentiel S.A., Belgium.

2 For current developments, see [http://europa.eu.int/comm/ employment_social/social_dialogue/news_en.htm].

\section{REFERENCES}

Borrás, S. and Jacobsson, K. (2004) 'The Open Method of Coordination and New Governance Patterns in the EU', Journal of European Public Policy 11(2): 185-208.

Casey, B.H. (2005) 'Building Social Partnership? Strengths and Shortcomings of the European Employment Strategy', Transfer 11(1): 45-63.

Council (1994) Report on the Essen European Council, Bulletin of the European Union, no. 12. Luxembourg: Office for Official Publications of the European Communities (OOPEC).

Council (1997) Report on the Special Luxembourg European Council on Employment, Bulletin of the European Union, no. 11. Luxembourg: OOPEC. Council (2000) Report on the Lisbon European Council. Bulletin of the European Union, no. 3. Luxembourg: OOPEC. 
Council (2001a) 'Council Decision of 19 January 2001 on Guidelines for Member States', Official Journal of the European Communities OJ L/22: 18-26, 24 January.

Council (2001b) 'Council Recommendation of 19 January 2001 on the Implementation of Member States' Employment Policies', Official Journal of the European Communities OJ L/22: 27-37, 24 January.

Council (2001c) Report on the Stockholm European Council, Bulletin of the European Union, no. 3. Luxembourg: OOPEC.

Council (2002) 'Council Recommendation of 18 February 2002 on the Implementation of Member States' Employment Policies', Official Journal of the European Communities OJ L/60: 70-80, 1 March.

Council (2005a) 'Council Decision of 12 July 2005 on Guidelines for the Employment Policies of the Member States', Official Journal of the European Union OJ L/205: 21-7, 6 August.

Council (2005b) Joint Employment Report 2004/2005, 9 March 2005, 7010/5, [http://register.consilium.eu.int/pdf/en/05/st07/st07010.en05.pdf].

Cutler, T. and Waine, B. (2000) 'Managerialism Reformed? New Labour and Public Sector Management', Social Policy and Administration 34(3): 318-32.

De Boer, R., Benedictus, H. and van der Meer, M. (2005) 'Broadening without Intensification: The Added Value of the European Social and Sectoral Dialogue', European Journal of Industrial Relations 11(1): 51-70.

De la Porte, C. and Pochet, P. (2003) Building Social Europe through the Open Method of Coordination. Brussels: PIE - Peter Lang.

EC (European Commission) (1988) 'The Social Dimension of the Internal Market', Interservice Working Party, SEC (88) 99.

EC (1993) Growth, Competitiveness, Employment. The Challenges and Ways Forward into the 21st Century. White Paper. Bulletin of the European Communities, Supplement 6/93. Luxembourg: Office for Official Publications of the European Communities.

EC (2002a) Communication from the Commission. The European Social Dialogue, a Force for Innovation and Change. Com (2002) 341 final. Brussels: EC.

EC (2002b) Impact Evaluation of the European Employment Strategy. Technical Analysis, Supporting COM (2002) 416 final of 17 July 2002 ('Taking Stock of Five Years of the EES'). Unit A2, Directorate-General for Employment, Industrial Relations and Social Affairs. Brussels: EC.

EC (2003) Recent Developments in the European Inter-professional Social Dialogue 2002-03. Unit D1, Directorate-General for Employment and Social Affairs. Brussels: EC.

EC (2004) Communication from the Commission. Partnership for Change in an Enlarged Europe - Enhancing the Contribution of European Social Dialogue. Com (2004) 557 final. Brussels: EC.

EIRO (2002) [http://www.eiro.eurofound.eu.int/2002/05/feature/ fr0205105f.html].

EIRO (2005) 'Social Partner Involvement in the 2002/03 National Action Plans', EIRO thematic feature. Dublin: European Foundation.

EIRR (2003) 'New National Collective Agreement', European Industrial Relations Review 349: 25-6. 
ETUC (2002) Social Partner Involvement in the NAP Process 2002. Brussels: European Trade Union Confederation.

ETUC, UNICE/UEAPME, CEEP (2004) 2004 Report on Social Partners' Actions in Member States to Implement Employment Guidelines. Brussels: ETUC, UNICE/UEAPME and CEEP [http://www.ueapme.com/EN/ policy_employment_european.shtml].

Falkner, G. (2003) 'The Interprofessional Social Dialogue at European Level: Past and Future', in B. Keller and H.-W. Platzer (eds) Industrial Relations and European Integration. Trans- and Supranational Developments and Prospects, pp. 11-29. Aldershot: Ashgate.

Ferner, A. and Hyman, R. (eds) (1998) Changing Industrial Relations in the New Europe. Oxford: Basil Blackwell.

Goetschy, J. (1999) 'The European Employment Strategy: Genesis and Development', European Journal of Industrial Relations 5(2): 117-37.

Goetschy, J. (2005) 'The Open Method of Coordination and the Lisbon Strategy: The Difficult Road from Potential to Results', Transfer 11(1): 64-80.

Gold, M., Cressey, P. and Gill, C. (2000) 'Employment, Employment, Employment: Is Europe Working?’, Industrial Relations Journal 31(4): 275-90.

Hodson, D. and Maher, I. (2001) 'The Open Method as a New Mode of Governance: The Case of Soft Economic Policy Coordination', Journal of Common Market Studies 39(4): 719-45.

Homs, O., Kruse, W., Lafoucrière, C. and Tilly, P. (2005) Contribution des organizations syndicales à l'évaluation des actions menées et de leur impact en termes de stratégie européenne pour l'emploi. Brussels: European Trade Union Confederation.

Keller, B. and Platzer, H.-W. (2003) Industrial Relations and European Integration: Trans- and Supranational Developments and Prospects. Ashgate: Aldershot.

Keller, B. and Sörries, B. (1999) 'The New European Social Dialogue: Old Wine in New Bottles?', Journal of European Social Policy 9(2): 111-25.

Kok, W. (2003) 'Enlarging the European Union: Achievements and Challenges' (the 'Kok Report'). Florence: European University Institute, Robert Schumann Centre for Advanced Studies.

Lecher, W., Platzer, H.-W., Rüb, S. and Weiner, K.-P. (2002) European Works Councils: Negotiated Europeanization. Aldershot: Ashgate.

Scott, J. and Trubek, D.M. (2002) 'Mind the Gap: Law and New Approaches to Governance in the European Union', European Law Journal 8(1): 1-18.

Teague, P. (1999) Economic Citizenship in the European Union: Employment Relations in the New Europe. London and New York: Routledge.

Van Ruysseveldt, J. and Visser, J. (eds) (1996) Industrial Relations in Europe. Traditions and Transitions. London: Sage.

Watt, A. (2004) 'Reform of the European Employment Strategy after Five Years: A Change of Course or Merely of Presentation?', European Journal of Industrial Relations 10(2): 117-37.

Zeitlin, J., Pochet, P. and Magnusson, L. (eds) (2005) The Open Method of Coordination in Action: The European Employment and Social Inclusion Strategies. Brussels: PIE - Peter Lang. 
MICHAEL GOLD is Senior Lecturer in European Business and Employee Relations in the School of Management, Royal Holloway University of London.

ADDRESS: School of Management, Royal Holloway University of London, Egham, Surrey TW20 0EX, UK. [e-mail: m.gold@rhul.ac.uk]

PETER CRESSEY is Reader in Sociology in the Department of Social and Policy Sciences, University of Bath.

ADDRESS: Department of Social and Policy Sciences, University of Bath, Claverton Down, Bath BA2 7AY, UK. [e-mail: hsspc@bath.ac.uk]

EVELYNE LEONARD is Professor at the Institut d'Administration et de Gestion, and President of the Institut des Sciences du Travail, Université catholique de Louvain.

ADDRESS: Université catholique de Louvain, Institut d'Administration et de Gestion - Institut des Sciences du Travail, Place des Doyens 1, BE-1348 Louvain-la-Neuve, Belgium. [e-mail: Leonard@rehu.ucl.ac.be] 